interval of stimulus presentation and blackout was identical to that of Phase 1 . RESULTS AND DISCUSSION

Figure 1 presents data demonstrating that object orientation does constitute a stimulus generalization dimension. The gradients were obtained during the first daily generalization testing session. For each $S$, responding to test orientations was expressed relative to the $S+$ response rate and multiplied by 100 . The response rates of the two Ss of Phase 2 were also transformed in this manner, and then an average of these relative response rates was plotted as Fig. 2. This first daily gradient of Phase 1 (Fig. 1), taken with that of Fig. 2, presents an especially clear picture of the generalization function for the object-orientation dimension. There appears to be a fairly linear decrement in responding at orientations near the peak of the gradient, particularly in Fig. 2 .

The failure to obtain a peak shift during the second phase of the study was not totally unexpected. This phase was undertaken with the knowledge that Ss had a rather extensive history of discrimination training with several symmetrically spaced $S-$ 's when one considers the discrimination training intrinsic in the generalization testing of Phase 1. Our pointing to the experience prior to Phase 2 as relevant to our failure to obtain a peak shift is buttressed by the similarity between the last few generalization gradients of the first phase and the gradients generated during the second phase. That is, responding to the test stimuli that were common to both generalization tests was essentially the same. Nevertheless, the more closely spaced generalization gradient generated in this phase of the study does provide unequivocal evidence that the orientation of a three-dimensional object constitutes a dimension of stimulus generalization capable of quite definitive stimulus control.

\section{REFERENCES}

BUTTER, C. M., \& GUTTMAN, N. Stimulus generalization and discrimination along the dimension of angular orientation. American Psychologist, 1957, 12, 449. (Abstract)

GUTTMAN, N., \& KALISH, H. I. Discriminability and stimulus generalization. Journal of Experimental Psychology, 1956, 51,79-88.

REYNOLDS, G, S. Contrast, generalization, and the process of discrimination. Journal of the Experimental Analysis of Behavior, 1961, 4, 289-294.

VETTER, G. H., \& HEARST, E. Generalization and discrimination of shape orientation in the pigeon. Journal of the Experimental Analysis of Behavior, 1968, 11, 753-765. NOTES

1. This study is based in part on a thesis presented by the second author to the Graduate School, University of North Carolina at

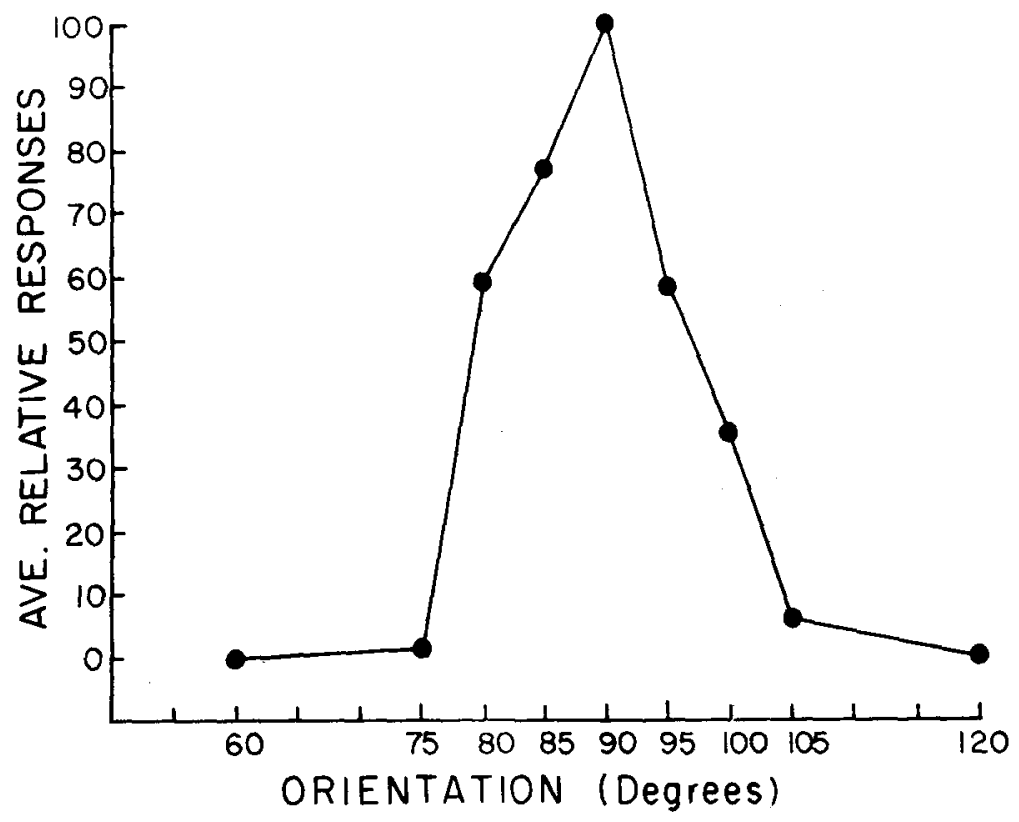

Fig. 2. Relative generalization gradient following on-continuum discrimination training with $90 \mathrm{deg}$ as $\mathrm{S}+$ and with $75 \mathrm{deg}$ as $\mathrm{S}-$. The gradient is based on the averaged relative responses of two Ss.

Greensboro, in partial fulfillment of the requirements for the MA degree.
2. The second author is currently at Central Piedmont Community College, Charlotte, N.C.

\title{
Sand digging of C-57 mice ${ }^{1}$
}

\section{W. E. WILSONCROFT, San Fernando Valley State College, Northridge, Calif. 91324}

The present study explores the sand-digging behavior of a highly inbred strain of mice (C-57) to see if they, like Peromyscus and laboratory rats, will volunteer to dig large amounts of sand in the absence of primary rewards. The effects of training (pacing) are also examined.
Digging is a common rodent behavior, and as early as the 1930s Stone (1937) showed that rats would dig sand from a tube that blocked heir access to food. Some 20 years later, Earl (1957) noted that mice would volunteer to dig sand without any primary reinforcement; this finding was used as an example of "autonomous" motivation by Bindra (1959).

Several more recent studies on sand-digging behavior have also shown that 


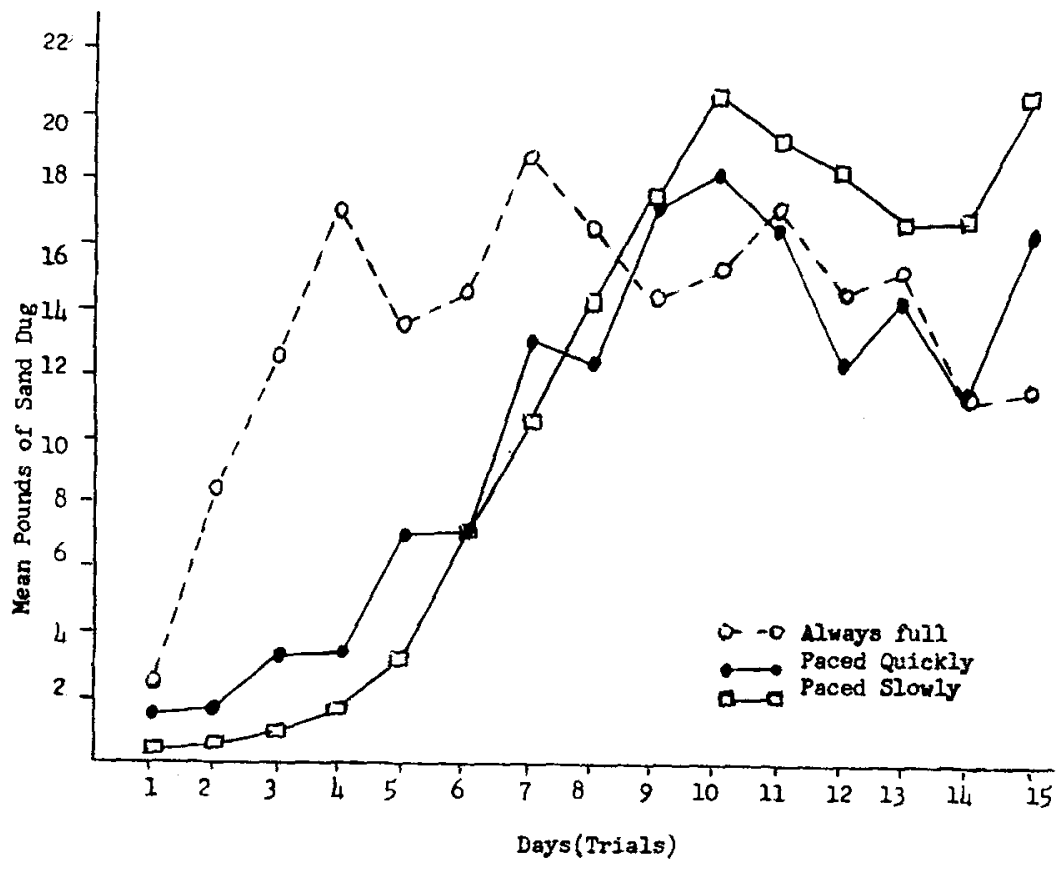

various species will dig large amounts of sand with no apparent reward other than the digging activity. King \& Weisman (1964) studied sand digging in five strains of Peromyscus (deermice). They found species differences in operant digging behaviors and were also successful in getting Ss to press a bar for the opportunity to dig sand. Shupe (1967) examined the effects of training (pacing) on sand digging in laboratory rats. He found that rats could be paced (given daily increases in the amount of sand obstructing their passage through a tube) to dig at rates of $1 \mathrm{lb}$ of sand per minute for up to $140 \mathrm{lbs}$ of sand, which was over 200 times the Ss' own body weights. However, rats that were not paced (i.e., were exposed to infinite amounts of sand on the initial and all following trials) failed to dig any sand at all.

The present study explores the sand-digging behavior of a highly inbred strain of mice (C-57) to see if they, like Peromyscus and laboratory rats, will volunteer to dig large amounts of sand in the absence of primary rewards. The effects of training (pacing) will also be examined.

\section{METHOD}

The Ss were 15 inbred male mice (C-57) obtained from the Genetics Laboratory at the University of California, Berkeley. The apparatus consisted of two empty chambers ( 7 in. square) connected by a 6 -in.-long plastic tube, 2 in. in diam. A vertical pipe, entering the middle of the plastic tube, allowed filling of the tube with sand from a large funnel above. All Ss were housed individually and were tested in $45-\mathrm{min}$ trials on each of 15 consecutive days.

The Ss were divided into three groups that were exposed to the following conditions: (1) Ss not paced-On each trial, Ss had an unlimited amount of sand delivered into the tube and thus could never dig their way into the second chamber. (2) Ss paced slowly-Daily increments of $0,20,40,80,160 \mathrm{~g}$, etc., of sand were delivered into the tube. (3) Ss paced quickly-Daily increments of 0 , $1,600,3,200,6,400 \mathrm{~g}$, etc., of sand were delivered into the tube.

\section{RESULTS}

The maximum amount of sand dug by a single $S$ in a $45-\mathrm{min}$ trial was $11,527 \mathrm{~g}$ (25.4 lbs), which was 384 times the S's body weight (this was a Group 2 S). Figure 1 shows that many Ss dug well over $10 \mathrm{lbs}$ of sand per 45-min trial.

The last 5 days of testing were used to compare the three groups since all Ss, in all groups, were unable to dig through the sand during these trials. The results are shown in Table 1. The Group 2 Ss (paced slowly), although they dug more than the other groups, narrowly missed being

Table 1

ANOVA on Pounds of Sand Dug on the Last Five Days When None of the Ss Got Through the Tube

\begin{tabular}{lrrrc} 
Source & SS & df & MS & F \\
Groups (G) & 7368 & 2 & 3684 & 3.71 \\
Error (a) & 11919 & 12 & 993 & \\
Trials (T) & 3843 & 4 & 961 & 1.45 \\
(G) X (T) & 2392 & 8 & 299 & \\
Error (b) & 31880 & 48 & 664 & \\
\hline
\end{tabular}

$p<.05=3.88$
Fig. 1. Mean number of pounds of sand dug on each of 15 testing days. $N=5$ per group, trials $=\mathbf{4 5} \mathrm{min}$. On the last 5 days, all Ss failed to dig through the tube.

significantly different from the other groups. Another analysis was run, using the first 5 days on which each individual $S$ failed to dig completely through the tube. That is, Ss in Group 3 (paced quickly) usually failed to dig through the tube a few days earlier than Ss in Group 2 (paced slowly). However, here again, no significant group differences were obtained $(F=2.58$, $\mathrm{df}=2 / 12$ ). It should be noted that all Ss, in all groups, did dig a large amount of sand.

\section{DISCUSSION}

The sheer magnitude of the work done by the Ss is the significant aspect of this study. Like the Peromyscus and laboratory rat, these highly inbred mice volunteered to dig large quantities of sand. Mice weighing $30-50 \mathrm{~g}$ routinely dug over $10 \mathrm{lbs}$ of sand $(4,540 \mathrm{~g})$ during a 45 -min trial.

Training or pacing had little effect in the present study. The Ss' prior experience with sand failed to differentiate between the groups during the last 5 days of testing (Table 1). Even Ss who never got through the tube into the second chamber dug at high rates after the first few days (see Fig. 1).

Several additional Ss have been tested in an apparatus with two tubes connecting the two chambers. One tube was left open so that Ss could easily just walk from one chamber to another, and the second tube was filled with an unlimited amount of sand. By the 5 th day of testing, these Ss were also digging over $10 \mathrm{lbs}$ of sand during their 45-min trial. These Ss did exhibit one curious behavior-they would dig first on one side of the sand-filled tube, then dash through the open tube and dig on the other side of the sand-filled tube. They continuously alternated their point of attack during the trials.

\section{REFERENCES}

BINDRA, D. Motivation: A systematic reinterpretation. New York: Ronald Press, 1959.

EARL, R. W. Motivation, performance and extinction. Joumal of Comparative \& Physiological Psychology, 1957, 50, 348-351.

KING, J, A., \& WEISMAN, R. G. Sand digging contingent upon bar pressing in deermice (Peromyscus). Animal Behaviour, 1964, 12 , 446-450.

SHUPE, D. V. Sand digging in rats. Unpublished Master's thesis, Claremont Graduate School, 1967.

STONE, C. P. A study of perseverance and frustration in working rats. Psychological Bulletin, 1937, 34, 721-743. NOTE

1. Paper presented at the Western Psychological Association, Vancouver, B.C., 1969. 